\title{
California Sea Otter (Enhydra lutris nereis) Census Results, Spring 2016
}

Data Series 1018 



\section{California Sea Otter (Enhydra lutris nereis) Census Results, Spring 2016}

By M. Tim Tinker and Brian B. Hatfield

Data Series 1018

U.S. Department of the Interior

U.S. Geological Survey 


\title{
U.S. Department of the Interior SALLY JEWELL, Secretary
}

\section{U.S. Geological Survey Suzette M. Kimball, Director}

\author{
U.S. Geological Survey, Reston, Virginia: 2016
}

For more information on the USGS - the Federal source for science about the Earth, its natural and living resources, natural hazards, and the environment—visit http://www.usgs.gov or call 1-888-ASK-USGS.

For an overview of USGS information products, including maps, imagery, and publications, visit http://usgs.store.usgs.gov

Any use of trade, firm, or product names is for descriptive purposes only and does not imply endorsement by the U.S. Government.

Although this information product, for the most part, is in the public domain, it also may contain copyrighted materials as noted in the text. Permission to reproduce copyrighted items must be secured from the copyright owner.

Suggested citation:

Tinker, M.T., and Hatfield, B.B., 2016, California sea otter (Enhydra lutris nereis) census results, spring 2016: U.S. Geological Survey Data Series 1018, 10 p., http://dx.doi.org/10.3133/ds1018.

ISSN 2327-638X (online) 


\section{Contents}

Abstract
Introduction
California Sea Otter Census Results
$\quad$ Range-Wide Summary
Regional Trends
Acknowledgments
References Cited

\section{Figures}

1. Map showing distribution of sea otters along the mainland coast and San Nicolas

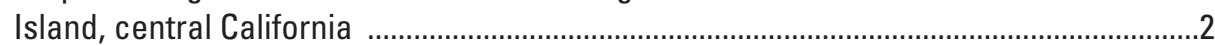

2. Graph showing trends in abundance of sea otters in California, based on 3-year running averages of raw counts ...................................................................................

3. Graph showing regional trends in abundance of sea otters along the mainland coast of central California .............................................................................................

4. Map showing variation in local population density of sea otters along the mainland coast, central California ......................................................................................................

5. Map showing local trends in abundance of sea otters along the mainland coast,



\section{Table}

1. Summary of spring survey counts of sea otters in California, and 3-year averages, 1990-2016. 


\section{Conversion Factors}

International System of Units to U.S. customary units

\begin{tabular}{|c|c|c|}
\hline Multiply & By & To obtain \\
\hline \multicolumn{3}{|c|}{ Length } \\
\hline meter (m) & 3.281 & foot (ft) \\
\hline meter (m) & 1.094 & yard (yd) \\
\hline kilometer (km) & 0.6214 & mile (mi) \\
\hline
\end{tabular}

\section{Datum}

Horizontal coordinate information is referenced to the North American Datum of 1983 (NAD 83). 


\title{
California Sea Otter (Enhydra lutris nereis) Census Results, Spring 2016
}

\author{
By M. Tim Tinker and Brian B. Hatfield
}

\begin{abstract}
The 2016 census of southern sea otters (Enhydra lutris nereis) was conducted in May along the mainland coast of central California and in April at San Nicolas Island in southern California. The 3-year average of combined counts from the mainland range and San Nicolas Island was 3,272. This is the first year that the official index has exceeded 3,090, the Endangered Species Act delisting threshold suggested by the U.S. Fish and Wildlife Service (the threshold would need to be exceeded for 3 consecutive years before delisting consideration). The 5-year average trend in abundance, including both the mainland range and San Nicolas Island populations, is positive at 3.2 percent per year; however, regional trends vary, with localized declines at the southern and northern peripheries of the mainland range. The lack of population growth in the range peripheries over recent years likely explains the cessation of range expansion, with the range limits remaining almost unchanged from the previous 5 years.
\end{abstract}

\section{Introduction}

A range-wide census is conducted each spring by the U.S. Geological Survey and partners (including California Department of Fish and Wildlife) to monitor trends in abundance and distribution of the southern sea otter (Enhydra lutris nereis), and thus provide State and Federal resource agencies with the information they need for effective management. The standardized census has been completed annually since 1982 (with the exception of 2011, when weather conditions prevented survey completion), using a combination of aerial surveys and shore-based counts, and provides an uncorrected and exhaustive count of the entire range of the sea otter in coastal California. Shore-based counts are used in all areas that are accessible by ground-based observers, except in a few regions where otters often move far off shore (such as shallow, sandy embayments) and are therefore difficult to count reliably from the shore. In these areas, aerial surveys are flown along contiguous transects oriented parallel to the shore and covering all areas between the coastline and the 60-m depth contour. Details of survey methods as well as data and metadata from previous years' surveys can be found at http://dx.doi.org/10.5066/F7FJ2DWJ.

The spring 2016 mainland sea otter count began on May 1 and was completed on May 11, 2016. Overall viewing conditions this year were very good, being more favorable than viewing conditions during the spring 2015 census (3.1 vs. 2.6 , where $0=$ poor, $1=$ fair, $2=$ good, $3=$ very good, and $4=$ excellent) and contributed to the relatively short duration of the count. The surface canopies of kelp (Macrocystis sp.) were considered by most census participants to be below normal for this time of year in the northern half of the range and about normal in the southern half. Sea otters along the mainland were surveyed from Pillar Point in San Mateo County in the north, to Rincon Point in the south at the Santa Barbara/Ventura County line (fig. 1). A separate ground-based survey of the sea otter population at San Nicolas Island was completed earlier (April 15-18). Surface kelp canopies at the time of survey at San Nicolas Island were estimated to be below normal near shore off the western end of the island and about normal elsewhere. Survey viewing conditions were very good $($ View Score $=3.0$ ). 


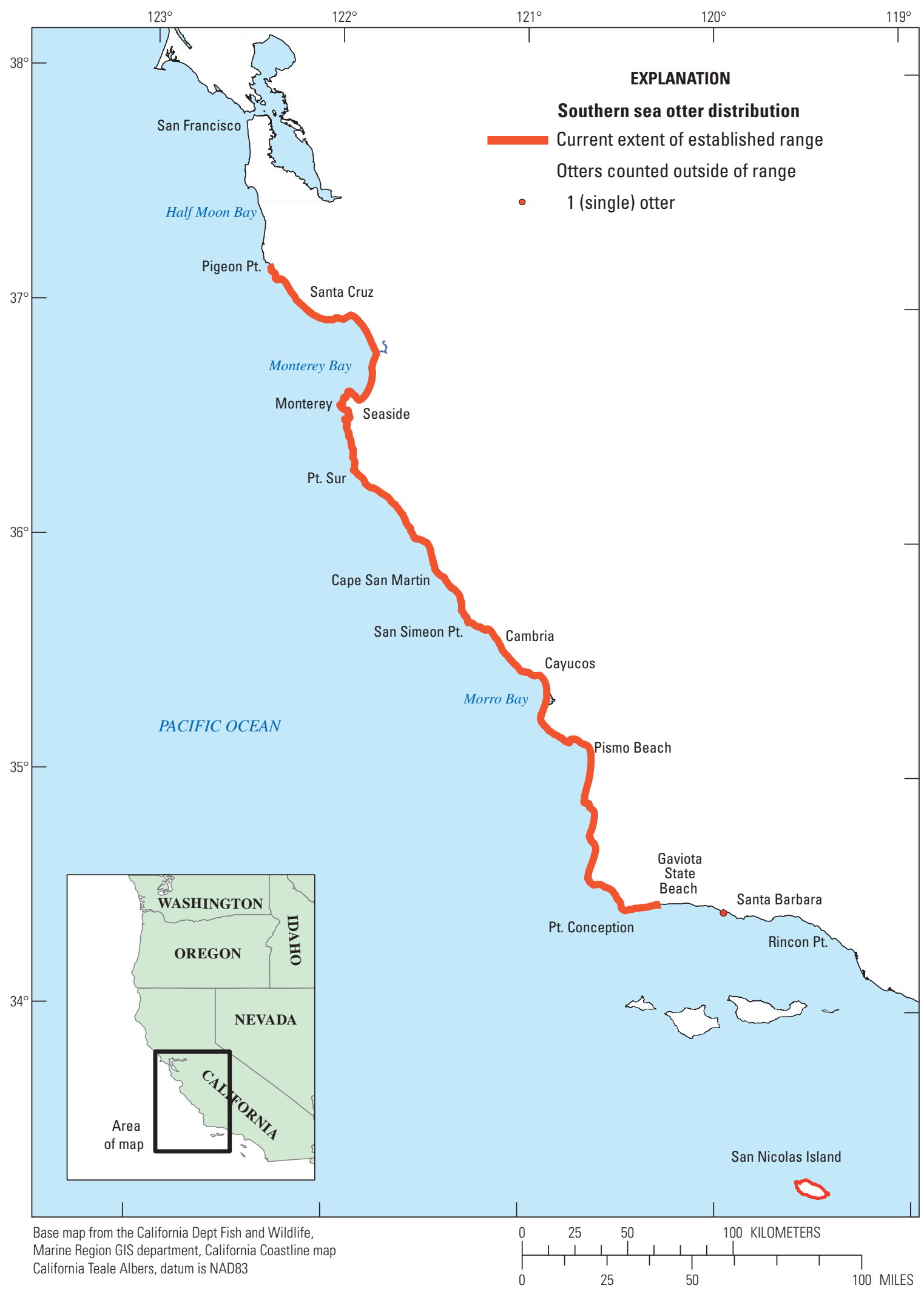

Figure 1. Distribution of sea otters along the mainland coast and San Nicolas Island, central California. 


\section{California Sea Otter Census Results}

\section{Range-Wide Summary}

The U.S. Fish and Wildlife Service's Southern Sea Otter Recovery Plan (U.S. Fish and Wildlife Service, 2003) recommends using the 3-year running average of total counts as the official metric for monitoring trends, thereby reducing the influence of anomalously high or low counts from any particular year. The 3-year average of combined counts from the mainland range and San Nicolas Island therefore comprise the official index of abundance for southern sea otters, the current value of which is 3,272 (table 1, fig. 2). For southern sea otters to be considered for removal from threatened status under the Endangered Species Act, the index of abundance must exceed 3,090 for 3 consecutive years, according to the threshold established under the U.S. Fish and Wildlife Service's Southern Sea Otter Recovery Plan (U.S. Fish and Wildlife Service, 2003). This is the first year (2016) the range-wide index of abundance has exceeded this threshold.

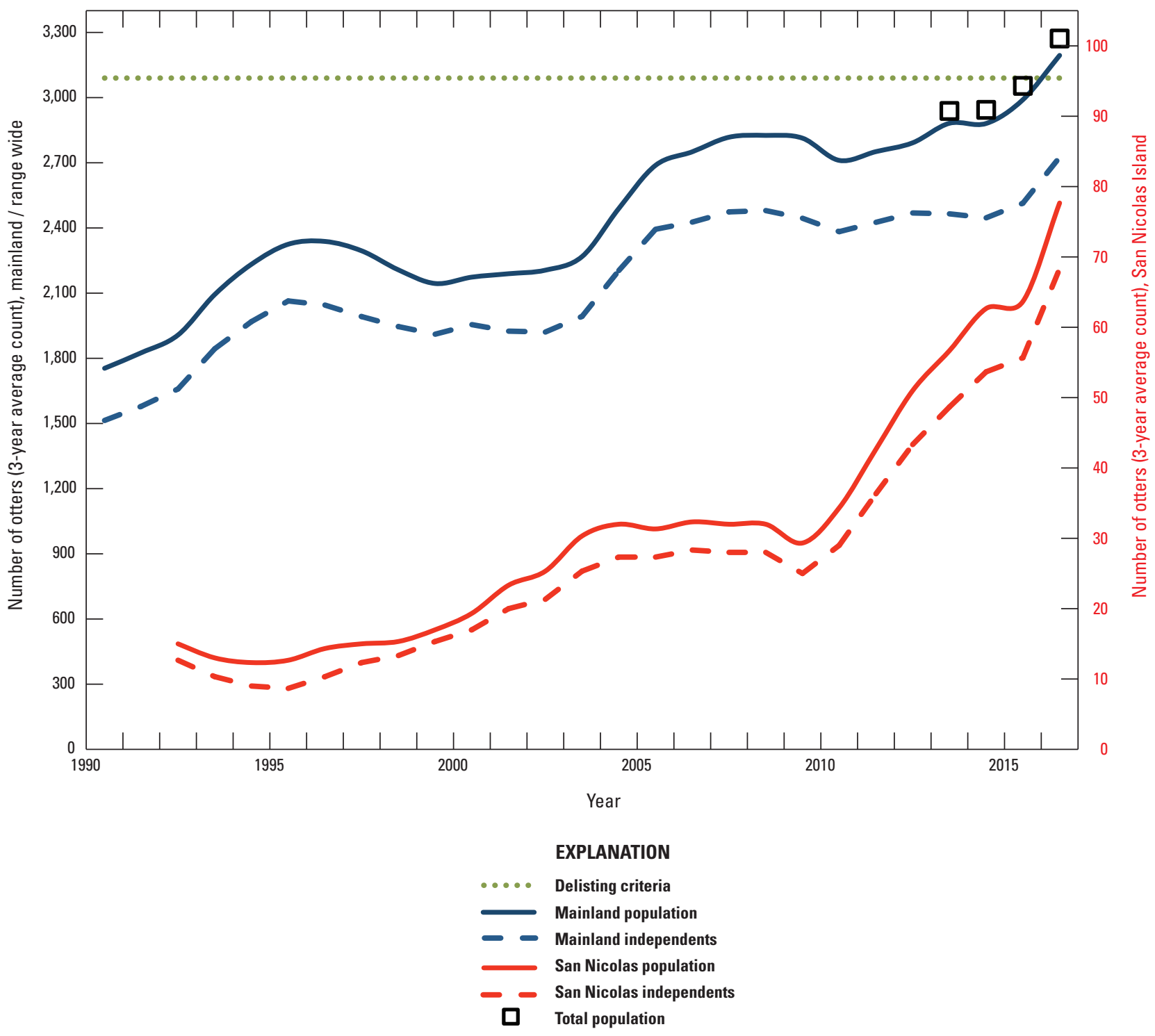

Figure 2. Trends in abundance of sea otters in California, based on 3-year running averages of raw counts. Data are shown for all otters and independents (non-pups) for the mainland range (left axis), San Nicolas Island (right axis), and for the entire range after 2012 (left axis) when counts were combined to create an official index of abundance. 


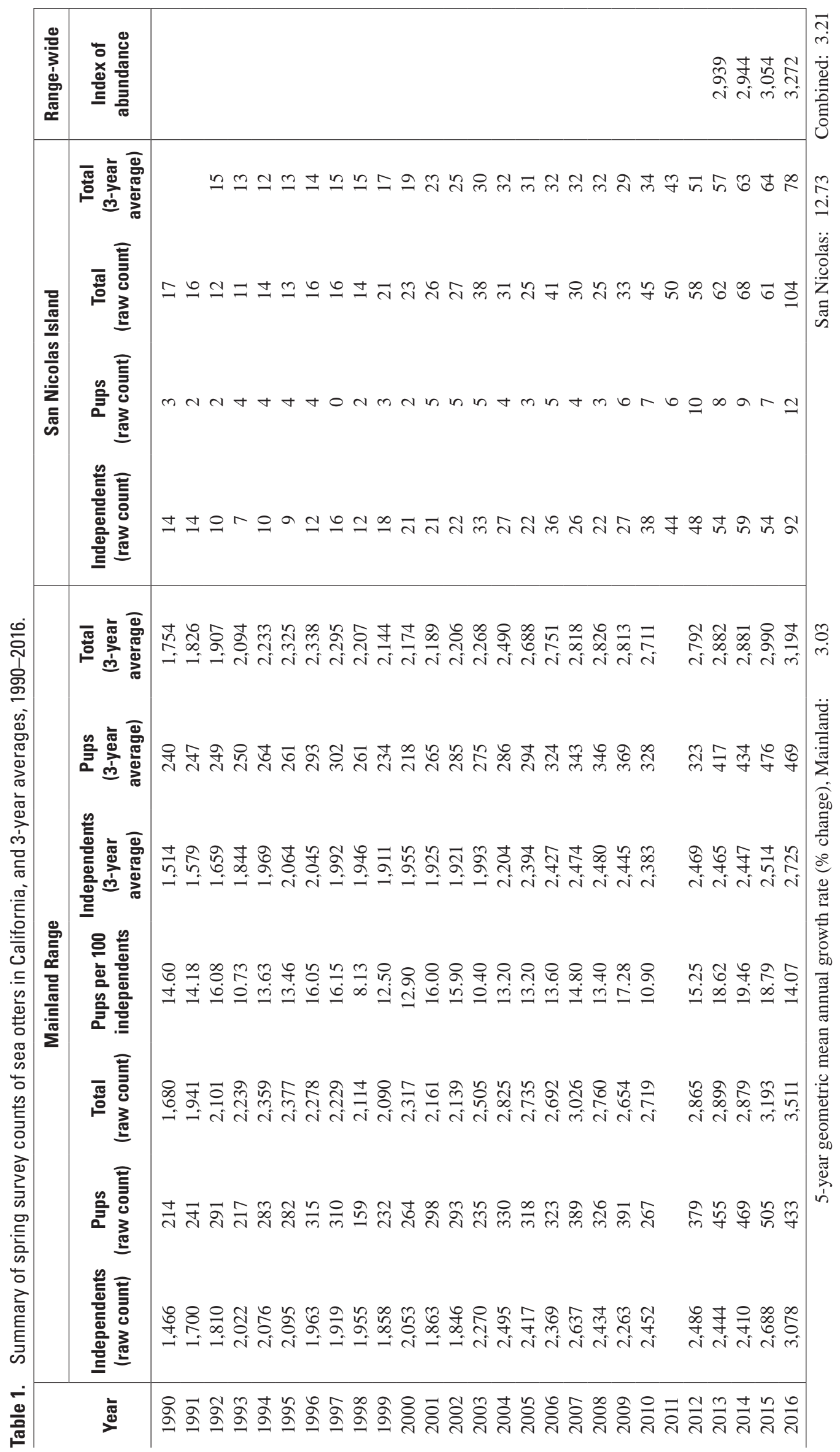




\section{Range-Wide Trends}

There is a considerable degree of uncertainty (random variation due to sampling and measurement error) in any one year's count, and thus longer term trends are far more informative than year-to-year differences. We therefore report average trends over the past 5 years, $\bar{\lambda}$, calculated as the geometric mean of $\lambda$, the annual rate of change (annual $\lambda$ values are computed by dividing the 3-year running average count by the equivalent value from the previous year, and thus $\lambda=1$ indicates a constant population). The 3 -year running average count of the mainland population is 3,194 (table 1), which is up considerably from previous years and reflects an increasing trend of approximately 3 percent per year $(\bar{\lambda}=1.03$; fig. 2$)$. The number of independent sea otters (juveniles and older) counted in the mainland range in spring 2016 was a record high, although the number of pups was lower, resulting in a pup index (number of pups per 100 independents) of 14, which is lower than average but still within the range of normal variation (table 1). The 3-year running average total count of the San Nicolas Island population is 78 (table 1 ), which continues a strong positive trend of approximately 13 percent per year $(\bar{\lambda}=1.13$; fig. 2$)$. The overall 5-year trend for southern sea otters, including both the mainland range and San Nicolas Island populations, is 3.2 percent per year $(\bar{\lambda}=1.03)$.

\section{Regional Trends}

Within the mainland range, regional trends in abundance vary considerably. In the center portion of the range, between the towns of Seaside and Cayucos (fig. 1), a second year of high counts (fig. 3) resulted in an increasing trend of 6 percent per year $(\bar{\lambda}=1.06)$. One potential explanation for the recent increase in numbers in this region is the dramatic increase in sea urchins (preferred sea otter prey) in some areas of the central coast, especially Monterey to Point Sur, which has led to increased juvenile survival. Although the 2016 census results are consistent with this hypothesis, the largest increase this year was seen in the southern parts of the central range (Cape San Martin to Cayucos), particularly in the numbers seen approximately $1-3 \mathrm{~km}$ from shore. Because we do not collect dietary data from sea otters in this area, we do not know whether this localized increase reflects a response to increased urchin abundance, some other abundant prey, or to what degree the exceptionally good viewing conditions for this survey section contributed to the high count of offshore animals.

To the north and south of the central region, the patterns are very different, with decreasing 5 -year trends of approximately -2.5 percent per year $(\bar{\lambda}=0.97)$ in the northern region and -0.6 percent per year $(\bar{\lambda}=0.99)$ in the southern region. These regionally decreasing trends (fig. 3 ) are consistent with an increase in shark bite mortality over the last 10 years in these peripheral areas of lower population density (fig. 4). Notably, the specific areas where the population trends are most negative (from Pigeon Point to north Monterey Bay, and from Cayucos to Point Conception; fig. 5) coincide exactly with the areas of increased shark bite mortality (Tinker and others, 2015). The lack of population growth in the range peripheries over recent years likely explains the cessation of range expansion, as it is growth at the range ends that typically fuels range expansion (Tinker and others, 2008; Lafferty and Tinker, 2014). 


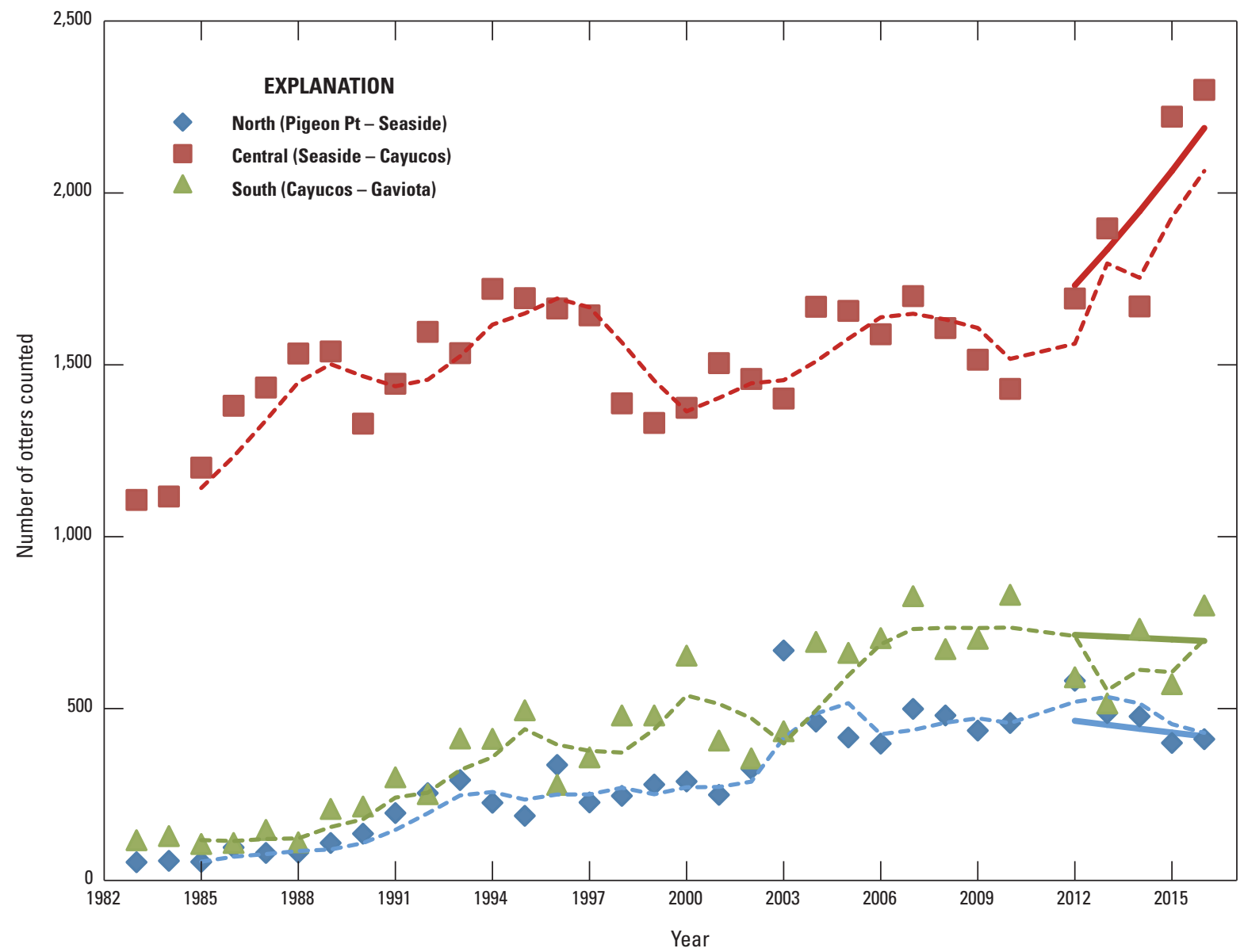

Figure 3. Regional trends in abundance of sea otters along the mainland coast of central California. Raw counts and 3-year running averages (dashed lines) are plotted for the north, central, and southern regions. The most recent 5-year average trend (calculated as the geometric mean annual rate of change) is shown as a solid line at the end of each time series. 


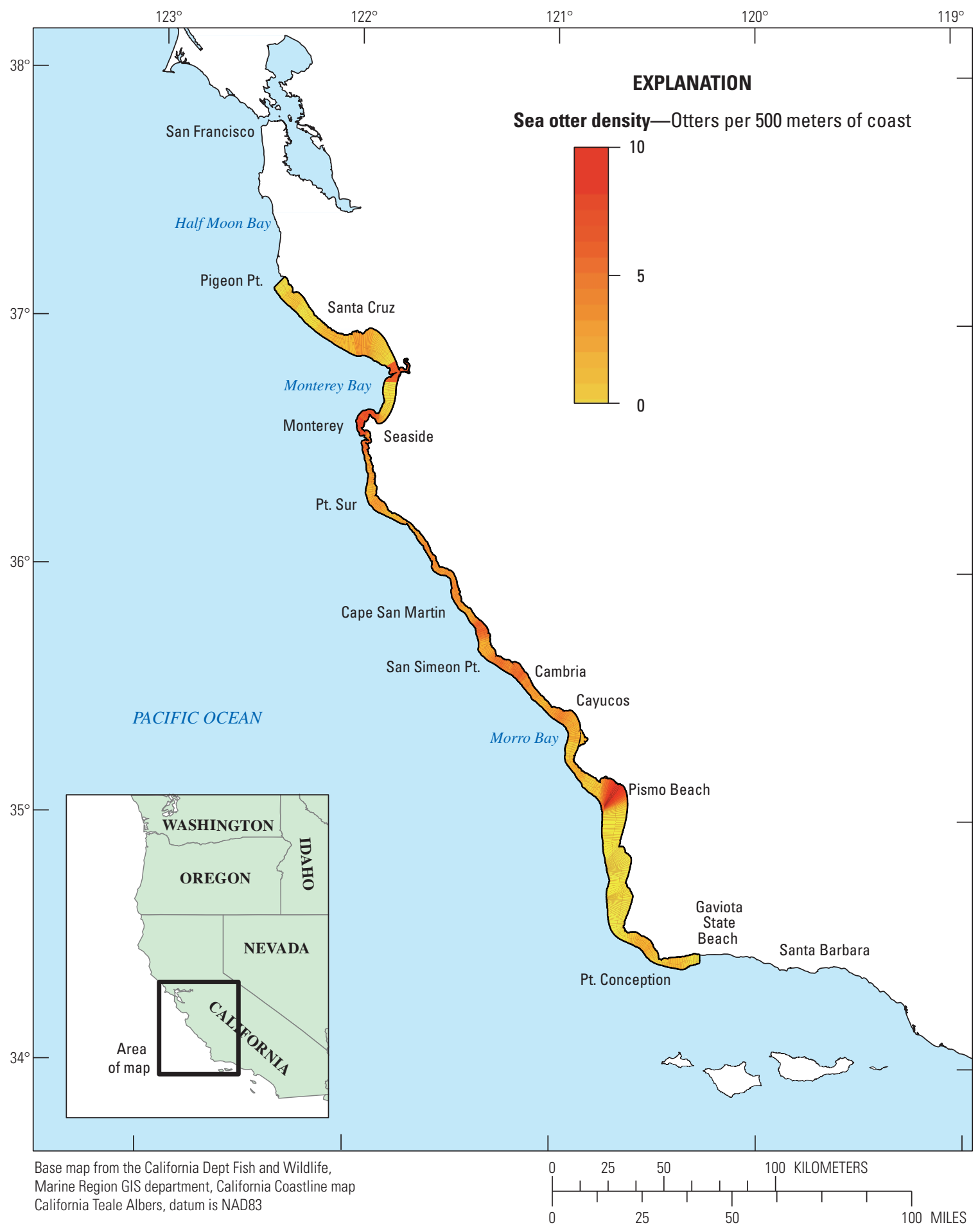

Figure 4. Variation in local population density (number of sea otters per 500 meters of coast) of sea otters along the mainland coast, central California. Data for San Nicolas Island are not shown because spatially explicit analyses are not currently conducted for San Nicolas. 


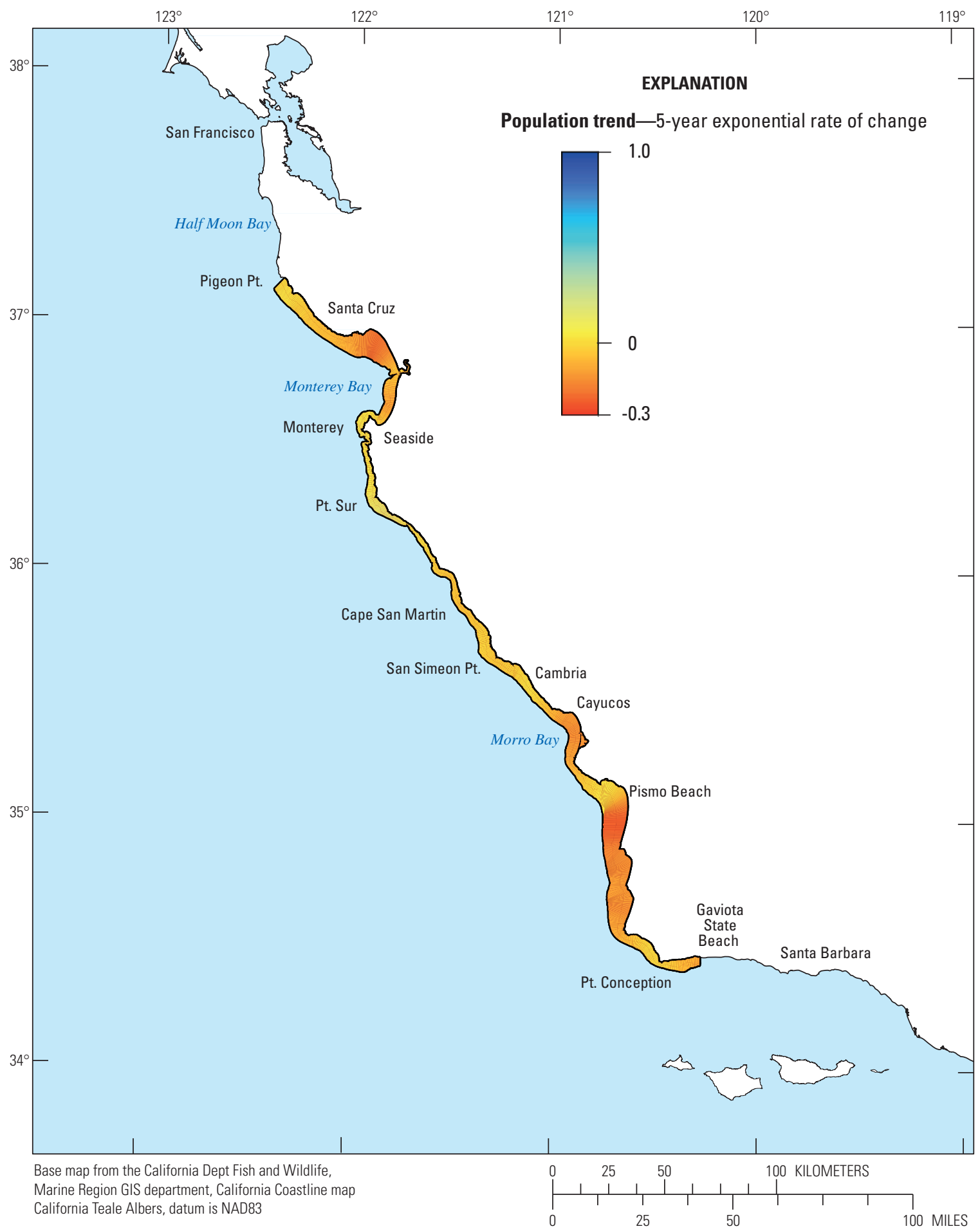

Figure 5. Local trends in abundance of sea otters along the mainland coast, central California. Trends represent 5-year exponential rates of change (fit using maximum likelihood). Data for San Nicolas Island are not shown because spatially explicit analyses are not currently conducted for San Nicolas. 


\section{Geographic Distribution}

The northernmost otters detected in this year's mainland survey were near Point Año Nuevo. At the southern end of the mainland range, 72 otters were counted southeast of Point Conception, 27 more otters than were counted during the spring 2015 census. One otter was counted this year southeast of Gaviota State Beach (at Naples Reef, near University of California-Santa Barbara). The northern limit of the sea otter's range along the mainland coast remains essentially unchanged from 2015. The northern boundary is considered to be approximately $2.5 \mathrm{~km}$ southeast of Pigeon Point. The southern limit of the range also was essentially unchanged from 2015, and is considered to be $6.5 \mathrm{~km}$ west of Gaviota State Beach (fig. 1). The mainland range limits are defined as the points farthest from the range center (to the north and south) at which 5 or more otters are counted within a $10 \mathrm{~km}$ contiguous stretch of coastline (as measured along the $10 \mathrm{~m}$ bathymetric contour) during the two most recent spring censuses, or at which these same criteria were met in the previous year.

Further data summaries and GIS data, as well as detailed methods and metadata, are available online at http://dx.doi. org/10.5066/F7FJ2DWJ (Tinker and Hatfield, 2016).

\section{Acknowledgments}

The annual census is a cooperative effort between USGS-Western Ecological Research Center, California Department of Fish and Wildlife-Marine Wildlife Veterinary Care and Research Center, Monterey Bay Aquarium, University of California-Santa Cruz, U.S. Fish and Wildlife Service, and many experienced and dedicated volunteers. Assistance also was received from staff of the Bureau of Ocean Energy Management.

\section{References Cited}

Lafferty, K.D., and Tinker, M.T., 2014, Sea otters are recolonizing southern California in fits and starts: Ecosphere (Ecological Society of America), doi: 10.1890/ ES13-00394.1.

Tinker, M.T., Doak, D.F., and Estes, J.A., 2008, Using demography and movement behavior to predict range expansion of the southern sea otter: Ecological Applications, v. 18, no. 7, p. 1,781-1,794.

Tinker, M.T., and Hatfield, B.B., 2016, Annual California sea otter census-2016 spring census summary: U.S. Geological Survey data release, http://dx.doi.org/10.5066/ F7FJ2DWJ.

Tinker, M.T., Hatfield, B.B., Harris, M.D., and Ames, J.A., 2015, Dramatic increase in sea otter mortality from white sharks in California: Marine Mammal Science, v. 32, no. 1, p. 309-326, doi:10.1111/mms.12261.

U.S. Fish and Wildlife Service, 2003, Final revised recovery plan for the southern sea otter (Enhydra lutris nereis): U.S. Fish and Wildlife Service, Region 1, Portland Oregon, 58 p., accessed August 8, 2016, at https://www.fws.gov/ventura/ docs/species/sso/recoveryPlan/ssorecplan.pdf. 

Publishing support provided by the U.S. Geological Survey Science Publishing Network, Tacoma Publishing Service Center

For more information concerning the research in this report, contact the Director, Western Ecological Research Center

U.S. Geological Survey

3020 State University Drive East

Sacramento, California 95819

http://www.werc.usgs.gov/ 
